of physics, complete and accurate as they are, in no way exclude guidance of events by the agency of life or mind or other unknown influence" cannot, it appears to me, be regarded as true in any sense relevant to the main issue between naturalism and its opponents; that his contention holds because the psychic can be supposed to be sufficiently dexterous to apply all its interfering forces on matter "perpendicular to the direction of motion" is, to my thinking, a complete fallacy based upon an undue estimate of the importance of the conservation of energy as compared with a more general formulation of dynamics.

In an earlier part of his paper Sir O. Lodge has endorsed a somewhat different form of statement: "That life is something outside the scheme of mechanics, although it can nevertheless touch or direct material motion, subject always to the laws of energy and all other mechanical laws (the italics are mine) supplementing them, but contradicting or traversing them no whit." In this statement Sir $O$. Lodge has deigned to recognise the existence of the other mechanical laws. Considering that the motions of all the parts of a mechanical system are completely and uniquely determinate by means of the law of energy and all the other mechanical laws, it seems difficult to understand how room is left for supplementing these laws, or how the psychic can interfere in a mechanical system at all without traversing mechanical laws.

I have no intention of expressing any opinion whatever on the main point of dispute between naturalism and its opponents, or of discussing the question whether our ex. perience of the world can be adequately represented by a dualism of the physical and the psychical. My sole object has been to show that in suggesting that, provided the psychical does not generate energy, it does not, by the impressing of force, really interfere with the completeness of the system of physical laws, Sir O. Lodge has simply drawn a herring across the path of the controversy between naturalism and its opponents.

Christ's College, Cambridge, April 25.

\section{Density and Change of Volume of Nova Persei.}

DR. RITTER, when dealing with stellar atmospheres, touched upon the question of pulsation periods and changes of density of gaseous stars. His deductions are that the brightness of a variable (gaseous) star is inversely proportional to the square of its volume, and also that the period of pulsation varies inversely as the square of the star's density. Now Nova Persei's periods of pulsation have increased from about one day to five days and longer, from which changes, according to Dr. Ritter, we can estimate that the star's density has diminished from I/ Io to $I / 300$ of that of water. The square of the ratio of these two fractions is $1 / 900$. The brightness of Nova Persei should have decreased to this fraction, which is equal to a decrease of about seven magnitudes.

Important information as to the constitution of this star might be gained if a rigorous comparison between pulsation period and brightness could be carried out

Dr. Ritter's investigations will be found in Wiedmann's Annalen, 1879 , vol. viii. p. 177, and 1881 , vol. xiii. p. 367 .

\section{E. StRomeyer.}

\section{A Katydid's Resourcefulness.}

DURING the past summer an intimate friend of the writer's observed a peculiar case analogous to the Irishman's "spitting on his hands for a fresh hold." An ordinary katydid, in trying to climb along the slats of a window blind that were very smooth owing to the glazed surface of the paint, kept slipping on the smooth surface. It would raise one front leg and then the other, bringing the foot or claw to its inouth, and there wet it with the "molasses " which exuded from the creature's crop. Is this one of the practical uses made by the locust family of this sticky fluid to enable it to walk upon very smooth surfaces? If so, the writer has never had it brought to his notice before.

Iowa City, Ia., October, Igor. ARTHUR G. SMith.

\section{ABORIGINAL REMAINS IN N.W. FLORIDA.'}

' $\mathrm{HE}$ first of these two papers deals with archæological investigations along the coastal region of N.W. Florida, being a continuation of the searches conducted during ten successive seasons along other portions of the coast and the waterways running down to it. The work on this occasion was principally centred in the districts around Perdido Bay, Pensacola Bay, Santa Rosa Sound, and Choctawhatchee Bay. As has hitherto been the case in the investigation of Floridan antiquities, a rich harvest resulted, mainly of objects of pottery. This in spite of the excavation craze which has led numbers of unskilled searchers to probe the soil for its buried treasures. "In no part of Florida," writes Mr. Moore, " is the pursuit of this ignis fatuus so intense, and persons, otherwise sane, seemingly, spend considerable portions of their time with spade and divining rod in fruitless search." Some twenty mounds were investigated, and the paper is devoted mainly to a detailed description of the finds. Numerous interments were discovered; the greater number of the skeletons were, however, incomplete. The custom of burying the remains of the dead under inverted earthenware bowls of large size was evidently very prevalent, and recalls the similar practice observed by the pre-dynastic Egyptians. An interesting custom is revealed in connection with the pottery vessels found with the greater number of interments. Very many of the pots buried with the dead exhibit a hole purposely broken through the base, this having been done, it is believed, in order to "kill" the vessel to free its spirit to accompany that of the departed. This custom was seemingly very largely practised, and must have been associated with a system of primitive animistic philosophy which is almost world-wide, and which finds expression under different, though kindred, forms of manifestation.

The finding of a definite class of mortuary pottery is also of great interest. These ceremonial pots were usually small, often somewhat fantastic in form, and of poor materials, and a very interesting feature consists in their basal perforations having been made at the time of manufacture. These vessels were, in fact, made for ceremonial "killing "-one may say, were made ready-killed-and they served as cheap substitutes for the more valuable useful forms. A parallel is thus afforded to the modern Chinese practice of burning at funerals cheap paper models of useful objects, money, \&c., and to the specially-made valueless burial coins of Egypt and elsewhere.

The decoration upon the pots is for the most part bold in design, and incised or stamped, at times exhibiting zoomorphic or anthropomorphic themes in partial or complete relief. Some of the incised scrollwork is very skilfully executed, and gives a bold, intricate and effective pattern, notably in the case of a fine vase from a mound near Point Washington.

The second short paper deals with researches conducted along the Tombigbee River by the same explorers. A large number of mounds and camp sites were examined, and about I 78 miles of the river banks were searched. The results were disappointing, and but poorly rewarded the labour expended. The mounds were largely domiciliary, and the finds from them were few in number. The author gives a complete list of mounds and camp sites along the region examined, and of the names of the owners of the properties upon which they stand, and this should prove very useful to future investigators.

1 "Certain Aboriginal Remains of the North-West Florida Coast and the Tombigbee Riyer." "Two papers by Clarence B. Moore. Journ. of the, Academy of Natural Sciences of Philadelphia, second series (vol. xi., part 4, Igor.)

No. $1 ; 48$, VOL. 67] 